\title{
A New Course Connecting Working Post Skills and English Integrated Skills
}

\author{
Jiawu Yao \\ Guangdong Technical College of Water Resources and Electric Power, Guangzhou, China \\ Email: yaojw88@ sohu.com
}

\begin{abstract}
To meet the needs of the deepening reform of higher vocational education in China, a new course by the name of The Career English Integrated Skills, which combines the career skills and the career English integrated skills into a complex, has been lectured by the author in recent years. The concept of the course is based on the professional educational model "the duty actuation, the project guidance". Neither a public English nor an English for Specific Purposes, the course has its bright characteristic in taking the work mission or the professional project as a carrier, using the occupational post skills as the main content line, and making English integrated skills as its training way.
\end{abstract}

Index Terms—a new course, career skills, English integrated skills

\section{FOREWORD}

The deepening reform of higher vocational education in China proposed that the English teaching not only needs raising student's practical English abilities, but should raise student's English skills in the work-posts, the professional English accomplishment and the English sustainable development abilities. To meet those requirements a new course of The Career English Integrated Skills, which involves career English and the integrated career English skills, has been opened in our college in recent years. The contents of the course are introduced in the following.

\section{CAREER SKILLS}

Career skills can be defined as working post skills (career-common-core-skills), which may include:

A. The external affairs communicating skills, foreign trade professional skills(reception; welcomes delivers, unit introduction, product, item, project and contract settlement or service recommendation item and so on);

B. The practical official document writing skills, information acquisition skills, expressing work process skills (operation, gathering, disposition, demarcation, use, choice and so on);

C. The skills of expressing in solving the problems on the production process (service introduction, arrangement, designing, elimination, estimate, computation, choice, and so on);

D. The skills of expressing management in the organizing process (planning, organization, management, instruction, coordination, monitoring function, service introduction supervision, summary, report and so on).

\section{CAREER ENGLISH}

The English used in workplace today is becoming a new field of the English study in the world as people must get the job and the job must be done by using English. Nowadays when the global economy becomes existing, people perform their work with English skills-- the skills of listening speaking, reading, writing and interpreting or translating because English is the most important international language in the world.

In a sense, the Career English may be simply defined as a working language to express the general activities in the process of proper work or job. Compared with "English for Specific Purposes" (ESP), which is a special branch of English, with its own characteristic structure and vast terminology, the Career English is not too "specific" but encompasses the most domains of common English as well as the various language functions of the workplace. Within the course limits, the career English integrated skills will be practiced only but not the language general knowledge.

\section{THE INTEGRATED CAREER ENGLISH SKILLS}

All the communicating forms of the Career English involved in skills are integrated, not single because the investigation made in the past years from the career field shows that the sole-skill does not exist nearly in the real working activities.

The communicating forms of the Career English designed in the course are various:

A. The listening - speaking formula (Telling others what has been heard in English);

B. The listening - writing formula (recording what has been heard in English );

C. The reading — speaking formula (Telling others what has been read in English); 
D. The reading — writing formula (writing articles in his or her own language after reading materials in English);

E. The listening - translating formula (interpreting activities between the two languages);

F. The reading - translating formula (translation activities between the two languages).

The investigation we carried out proves that among the these integrated skills of Career English the end form of the communicating forms most used is to be speaking-writing- translating(interpreting) combination. Even if the obtained content of monitoring as the main task in military department finally still needs to have the written form to be presented. And editors need to use the written form to write out appraisals when reading magazines or newspapers as their chief work in editing.

Further in the analysis of the communicating activities taken outputs as the end form, we have also discovered the frequency of the interpreting and translating would appear far higher than that of speaking and writing. Generally, except the foreign capital companies, the transformation of Chinese and English can't be avoided in the joint venture or enterprises and institutions when English is used.

\section{The ENGLish InTEgRATED SKILls Training CONTENTS AND FORMS}

The career English integrated skills training content and form is indicated in the following table:

\begin{tabular}{|c|c|c|}
\hline & Training content & Training form \\
\hline \multirow{6}{*}{ Oral } & repeating the instructions of bosses & Recording while Listening and indicating to it \\
\hline & $\begin{array}{l}\text { After listening to business information reporting } \\
\text { back the outlining of them }\end{array}$ & Recording while Listening and expressing it orally \\
\hline & $\begin{array}{l}\text { Reading a diagram (photo, picture, etc.)of } \\
\text { products, then report the main point }\end{array}$ & Recording while reading and expressing it orally \\
\hline & $\begin{array}{l}\text { Watching the products video recording and } \\
\text { repeating it }\end{array}$ & Recording while reading and expressing it orally \\
\hline & Making an oral plan on a work task & Develops the lecture notes, the practicing lecturing in the crowd \\
\hline & $\begin{array}{l}\text { Making production or management reports on the } \\
\text { different viewpoints }\end{array}$ & $\begin{array}{l}\text { Thinking on the argument debates and writing out the } \\
\text { manuscript, attending the debate }\end{array}$ \\
\hline \multirow{8}{*}{ written } & $\begin{array}{l}\text { Reading product manuscripts and write out } \\
\text { outlines }\end{array}$ & $\begin{array}{l}\text { Reading and sectioning out the main plot, and composing } \\
\text { outlines }\end{array}$ \\
\hline & $\begin{array}{l}\text { Listening to work reports, writing out the main } \\
\text { points }\end{array}$ & Recording while listening and writing down main outlines \\
\hline & $\begin{array}{l}\text { Reading presentations of products then writing } \\
\text { summaries }\end{array}$ & $\begin{array}{l}\text { Reading reports and sectioning out the main points, and the } \\
\text { composing summaries }\end{array}$ \\
\hline & $\begin{array}{l}\text { Listening to presentations of products then writing } \\
\text { summaries }\end{array}$ & $\begin{array}{l}\text { Writing while listening then making the reading notes, } \\
\text { composing summaries }\end{array}$ \\
\hline & Writing out reading reports on the jobs & $\begin{array}{l}\text { Reading working process and recording the vital clues and } \\
\text { writing out reading reports }\end{array}$ \\
\hline & Writing out reports on work case analysis & $\begin{array}{l}\text { Reading working process and recording the vital clues and } \\
\text { writing out the case analyses }\end{array}$ \\
\hline & write a work summary & $\begin{array}{l}\text { Reading the related background material, and composing the } \\
\text { work summary }\end{array}$ \\
\hline & Write responses to customers & Reading proposals(complaints), then composing responses \\
\hline \multirow{7}{*}{ both } & The Interpreting foreign trade congress speech & Interpreting while listening \\
\hline & Interpreting in the business negotiations & Recording and interpreting while listening \\
\hline & Interpreting in the external affairs & Recording and interpreting while listening \\
\hline & The technical product written translation & carrying on translation while reading original text \\
\hline & Translating on technical materials in English & carrying on translation while reading original text \\
\hline & Translating on culture topics of foreign enterprises & carrying on translation while reading original text \\
\hline & translating on business scenic sites & carrying on translation while reading original text \\
\hline
\end{tabular}

\section{THE CAREER MAIN SKILLS AND MiCRO SKILLS}

The course contents are designed mainly into two parts: main skills and micro skills: 


\begin{tabular}{|l|l|}
\hline Main skills: work duties as the topic of the unit & Micro skills: career common core skill as the content of each unit \\
\hline Managing Office Work & Make and receive phone calls; \\
& Receive guests; \\
& Deal with daily routine work. \\
\hline Conducting a Survey & Talk about the process of a survey; \\
& Ask for opinions and suggestions; \\
& Sum up and report survey outcomes. \\
\hline Making Presentation & Make an effective presentation; \\
& Recognize different charts and diagrams; \\
& Describe a chart. \\
\hline Handling Personal Information & Give personal information; \\
& Ask about personal information ; \\
& Understand personal information through listening. \\
\hline Making Business Trips & Determine trip goals; \\
& Make trip arrangements; \\
& Contact business partners; \\
\hline
\end{tabular}

From the points of view on the course-unit design, there are career topics as learning tasks, each of which has a main skill (the first one)and a few micro skills(from the second of each number):

1. Adapting to New Environments

Know differences in the new place;

How to adapt to the new environment;

Manage daily life independently.

2. Handling Personal Information

Give personal information;

Ask about personal information;

Understand personal information through listening.

3. Planning Your Career

Talk about various occupations;

Talk about your ideal job;

Give reasons for the choice of a job;

Talk about a career plan.

4. Hunting for a Job

Find information about job opportunities;

Arrange for interviews;

Behave, ask and answer questions properly at an interview.

5. Making Invitations

Invite people to social and business activities;

Accept and decline invitations;

Create an invitation letter.

6. Catering Visitors

Pick up and send off visitors at the airport;

Book hotels and order food;

Negotiate agendas with visitors;

Show visitors around.

7. Managing Office Work

Make and receive phone calls;

Receive guests;

Deal with daily routine work.

8. Introducing a Company

Know the structure of a company;

Describe the main products and services of a company;

Make comments on the company culture: vision, goal, prospect of development.

9. Organizing Meetings

Make meeting arrangements;

Prepare for meeting materials.

10. Making Business Trips

Determine trip goals;

Make trip arrangements;

Contact business partners;

Pay a successful visit to your business partners.

11. Interpersonal Skills and Teamwork 
Get along well with colleagues;

Communicate effectively with the boss;

Cooperate with group members.

12. Conducting a Survey

Talk about the process of a survey;

Ask for opinions and suggestions;

Sum up and report survey outcomes.

13. Making Presentation

Make an effective presentation;

Recognize different charts and diagrams;

Describe a chart.

14. Working Process

Understand the functions and characteristics of a working process;

Form a working process with the help of a model;

Carry out a working process.

15. Quality Control

Tell the importance of quality control;

Know the quality control regulations/criteria;

Deal with the quality problem of products or services.

16. SYB (Set up Your Business) Online

Search information online;

Understand the process of SYB online;

Keep in touch with business partners online.

17. Global Sourcing

Know the widespread practice of global sourcing;

Tell the strategies in global sourcing;

Know the advantages and disadvantages of global sourcing.

18. Occupational Health and Safety

Talk about the importance of OHS;

Understand the OHS regulations;

Deal with OHS problems.

19. Modern Administration

Know the classification of modern administration

Know the links of modern administration

20. Retrospect and Prospect

Summarize the achievements in the previous year;

Analyze the causes of the weaknesses in the past year;

Plan for the coming year.

The teaching directions in each unit are made a table as the below:

\begin{tabular}{|l|l|l|l|}
\hline $\mathrm{U}$ & Career Skills & Detailed Descriptions & Assignments \\
\hline 3 & Promoting Products & 1. Can describe the products and services & LS: Related voc \& sp \\
& and & 2. Can compare products and services (features, prices) & R: Related passage \\
& Services & $\begin{array}{l}\text { 3. Can offer after-sale services } \\
\text { 4. Can conclude a deal and express wish for future } \\
\text { co-operation }\end{array}$ & functions \\
\hline
\end{tabular}

Notes: In the above table, "U" stands for "UNIT"; Career Skills means main skill; Detailed Descriptions equal to micro skill; LS, R and W/T in Assignments are referred to listening and speaking, reading and writing/translating.

In this unit the skills for career positions students need to learn and master are to promote their products and services, especially to be able to describe the products and services, to compare products and services and to provide after-sales service into a peace deal and long-term cooperation.

The comprehensive skills students need in this unit are : listening, speaking skills related to vocabulary and sentence patterns involving products and services; reading several articles in marketing products, services ,the product appearance and functions and writing, translation activities.

\section{An EXAMPLE OF A Unit DESIGN}

The following is one of the units of the course as an example of the course learning:

Task x Making Business Trips

English Integrated Skills: Listen and Complete

(main skill) Making Business Trips 
(micro skills) Listen and Complete; Read and Choose; Listen and Speak; Read and Match and Translate Career English Skills:

(main skill) Determine trip goals by planning in advance

(micro skills) Make trip arrangements; Contact business partners; Write a business trip review.

Reference words: Venue, transportation, means, exchange ,advisable; itinerary, destination, confirm, evaluate, supply, foreign currency, travel agency, have a business trip to ,hold talks with ,a red eye flight ,promote our products sales channel, expand one's business

\section{Activity 1 Listen and Complete}

Listening to the passage and complete the following paragraph.

When you're going for your business , there are many things you have to consider in advance. So it is advisable to write out an . If you are asked to make the travel arrangements yourself, you may consult a to book flight and hotel rooms. When these are set down, inform your business partner of the dates of your to buy too expensive things. Sending for business partners is a common practice. However, it is not necessary

(Keys: 1. trip 2. itinerary 3. travel agency 4. arrival and departure 5. gifts)

\section{Activity 2 Read and Choose and Answer}

\section{Travel for Business}

When you're going for your business trip, there are many things you have to consider in advance, such as finding out the location of the venue, choosing transportation means, booking hotel rooms, and even exchanging foreign currencies when traveling internationally. So it is advisable to write out an itinerary before you get to your destination. As a matter of fact, a good travel plan can save you a lot of time and money.

First of all, you must make yourself clear of your business trip goals, which may be to pay a visit to workshop, confirm quality standard, evaluate supply ability, discuss prices furthermore and so on. Make sure you keep all your goals in mind during the journey. If you are asked to make the travel arrangements yourself, you may consult a travel agency. Tell the assistants of the date and place, and they can always help you book flight and hotel rooms at more favorable prices.

When these are set down, inform your business partner of the dates of your arrival and departure so as to let your partner make some preparations for warming reception and help you book tickets for train or plane between cities. Name cards are often exchanged officially when you meet with your business partners for the first time. Usually customers will visit several places in different cities. It's a good idea to decide when and where to go first, second, third. It is quite important that both of you communicate in an effective way. If you are not sure which the best route is, you'd better consult your partner.

Nowadays, sending gifts for business partners has developed into a common practice. Gifts are just to express your sincerity to do business with your partners and it is not necessary to buy too expensive things for that. Otherwise, it is likely that you will make your partners feel nervous.

Based on the tips given ahead, you are likely to have a successful business trip with your partners around the world. (340 words)

2-1 Tell if the following statements are true or false.

1) It is suggested that we should make a plan before we start to travel.

2) We can consult a travel agency if we have to make the arrangements ourselves.

3) A travel agency always books flight and rooms at very high prices.

4) Inform the partners of the arrival date so that they can make some preparations.

5) Name cards are often exchanged officially when business partners meet for the first time.

6) We should buy expensive gifts for our business partners to express sincerity.

(Key:1. T2. T3. F4. T5. T 6. F)

2-2 Listen to the following questions and answer them.

1. What do we have to consider in advance when we're going for a trip?

2. In what way can a good travel plan help us?

3. What can we benefit from a travel agency?

4. Why should we inform business partners of the dates of arrival and departure?

5. Is it necessary to send too expensive gifts for business partners?

6. If you are going to have a business trip, how will you make a plan?

(Key: 1 We have to consider many things, such as finding out the location of the venue, choosing transportation means, booking hotel rooms, and even exchanging foreign currencies when traveling internationally.

2 A good travel plan can save us a lot of time and money.

3 A travel agency can always helps us book flight and hotel rooms at more favorable prices.

4 We inform them so as to let them make some preparations for warming reception and help us book tickets for train or plane between cities.

$5 \mathrm{No}$, it isn't. Because too expensive gifts will probably make your partners feel nervous.

6 Open.) 
Activity 3 Read and Match
A
1. 质量标准
B
2. 接风洗尘
a. supply ability
3. 交通工具
b. a common practice
4. 惯例
5. 供给能力
c. in an effective way
6. 商谈价钱
d. quality standard
e. transportation means
f. warming reception
7. 表示诚意
g. express the sincerity
8. 交通工具
h. exchange foreign currencies
9. 兑换外汇
i. transportation means
10 . 有效的
j. discuss prices
(Key:1-d 2-f $\quad 3-\mathrm{i} \quad 4-\mathrm{b} \quad 5-\mathrm{a} \quad 6-\mathrm{j} \quad 7-\mathrm{g} \quad$ 8-e $\quad 9-\mathrm{h} \quad$ 10-c)

\section{Activity 4 Read and Translate}

China Southern Airlines is an airline based in Guangzhou in the Guangdong province of the People's Republic of China operating domestic, regional and international services. China Southern is the world's 7th largest airline in terms of passengers carried in 2007, and Asia's largest airline in terms of both fleet size and passengers carried. China Southern is also the 7th busiest in domestic passenger traffic and the 7th largest in scheduled domestic passenger-kilometres flown worldwide. China Southern carries more domestic cargo than any other airline. It is a member of the SkyTeam airline alliance. Its main operation hubs are Guangzhou Baiyun International Airport and Beijing Capital International Airport, and a number of international airports in other big cities, like Changchun, Dalian, Shenzhen, etc.

Keys (Three kinds for students to appreciate)

No:1 中国南方航空公司是中国国内和国际航空,总部在广东广州。以载客能力计,南方航空是世界第七大,而按 机数和客量则为亚洲第一。中国南方航空还拥有全世界第七大国内客运量和国内旅客飞行公里数。它比中国任 何其他航空公司运载量更大。它还是国际 SkyTeam(国际航空联盟)的成员。它的主机场是广州白云国际机场和北 京首都国际机场及长春、大连、深圳等等大市国际机场。(166 Chinese words)

No:2 总部广州,中国南方航空公司服务国内、国际。其载客量,旅客飞行公里数居世界第七，机数、客量亚洲 第一。主机场广州白云及北京、长春、大连、深圳等国际机场。(73 Chinese words)

No:3 南航经营, 国内国际; 载客、航数,世界第七; 机数、客量, 亚洲第一; 一流机场, 广州白云。(42 Chinese words)

\section{Activities outside class}

1. Read the passage and fill in the blanks with appropriate words from the box below.

\begin{tabular}{|lllll|}
\hline $\begin{array}{l}\text { invited } \\
\text { assigned }\end{array}$ & $\begin{array}{l}\text { appreciation } \\
\text { destination }\end{array}$ & $\begin{array}{l}\text { due to } \\
\text { attached }\end{array}$ & $\begin{array}{c}\text { as soon as } \\
\text { aboard }\end{array}$ & $\begin{array}{l}\text { strengthen } \\
\text { looked forward to }\end{array}$ \\
\hline
\end{tabular}

\section{A Trip to Australia}

My name is Li Li. I work at a well-known wine import company in Guangzhou. Last week, my colleague John and I were 1 to visit our new business partner in Australia. We booked two flight tickets from a travel agency. John seemed a bit excited since it was his first time to travel by plane. On that day, 2 International Airport, we checked in. However, we waited two more hours until we could get 3

The whole journey was rather tiring. It took us more than eight hours to get to our first 4 we got to the Baiyun we walked out the terminal, a woman named Jane came to meet us. She was the assistant manager from the partnership company. 5 the fact that we were the potential importer, she told us that her company 6 great importance to our arrival. We expressed our deepest 7 for their considerate arrangements.

During the following days, we had several talks with the main leaders of their company. We discussed many fields in which we could 8 our cooperation. We also 9 the prospect that the products could be successful on the Chinese market in the near future. The company arranged us to visit their wine factory in Melbourne, where we surveyed their producing procedures and tasted the flavorful wine.

We had a wonderful time in Australia. When we finished our trip, we exchanged our gifts with the host. We also 10 them to come to China the next year.

(Keys: 1 assigned 2 as soon as 3 aboard 4 destination 5 Due to 6 attached 7 appreciation 8 strengthen 9 looked forward to 10 invited)

2. Choose the answer that best completes each sentence according the above passage.

1. John was excited because

A) he hadn't traveled by air before

B) Australia was his dream travel place

C) they had to wait for two hours at the airport 
D) he was traveling with $\mathrm{Li} \mathrm{Li}$

2. The word "potential" in paragraph 2 most probably means

A) probable

B) suitable

C) reliable

D) reasonable

3. The Australian company put high value on the author's arrival, because

A) they were rich people

B) they could probably import their wine

C) they could bring high technology to the company

D) they were from China

4. The author did many things except

A) having talks with the leaders of the company

B) discussing their cooperative fields

C) looking forward to the prospect on the Chinese market

D) exchanging their products

5. We can infer from the passage that

A) John has traveled to many countries before this trip

B) the flight was better than expected

C) the author had a successful business trip in Australia

D) Jane went to see the author off at the airport

(Keys:1 A, 2 A, 3 B, 4D, 5 C)

\section{CONCLUSION}

The general goal of the course The Career English Integrated Skills is to aim at the actual use of English in scene segmentation in societies, workplaces and posts. Mainly to professional trends and the higher vocational English teaching needs, the practical knowledge and abilities of both career and English skills are carefully extracted and selected to combine into the formation of a professional job working ability of the Can Do Lists, into a professional micro-skills group to form a cross-skills training of listening, speaking, reading, writing and translation.

The Career English Integrated Skills is a new course connecting working post skills and English integrated skills and being a newly built module system in English education reform, much work needs to be done in the coming time, such as the design of the textbook, including its compilation themes, compilation styles, as well as the study patterns and the matched resources.

\section{REFERENCES}

[1] Qiufang Wen. (2008). Output actuation supposition and curriculum reform of English professional skill, Beijing: Foreign Language World .

[2] Shihong Dai . (2007). The case collection of Quality education in curriculum project. Beijing: Qinghua University Press

[3] The Ministry of Education of People's Republic of China. (2004). The certain opinions about further strengthen the vocational education by the Ministry of Education and seven ministries and commissions opinions

[4] The Ministry of Education of People's Republic of China. (2006). The certain opinions about improvement on the higher vocational education quality

[5] Jiawu Yao. (2009).Integrating the work mission and aiming at the ability goal - On English curriculum construction and the innovation of skill system innovation. Journal of Guangdong Technical College of Water Resources and Electric Power.

Jiawu Yao was born in Wuhan, China in 1954. He received his M.A. degree in linguistics from Huanan Normal University, China in 2004.

$\mathrm{He}$ is currently an associate professor in the Department of Applied Foreign Languages, Guangdong Technical College of Water Resources and Electric Power, Guangzhou, China. His research interests include foreign language teaching and translation.

Professor Yao is a member of the China Translation Association. 